\title{
THE PERSPECTIVE OF CIRCULAR FOOD WASTE MANAGEMENT IN THE COMBINED CASE OF BAKERY AND BREWERY
}

\author{
Alan DYMCHENKO ${ }^{1}$, Milan GERŠL ${ }^{1}$, Tomáš GREGOR ${ }^{1}$
}

Mendel University in Brno, Faculty of AgriSciences ${ }^{1}$

\begin{abstract}
This work is focused on issues related to the circular economy of gastronomic waste, namely the reuse of residual products from bakeries in beer production in order to reduce the amount of waste from bakery leftovers and their use as a substitute for malt in brewing. The main aim is to verify the possibility of using bakery leftovers with the help of fermentation technologies (the production of alcoholic beverage from the bakery leftovers). Bakery leftovers in the form of ordinary bread are obtained from the bakery pilot plant. After the analyses, these leftovers are used for beer production.

Conducting research on the proposed topic will allow us to look at the production of beer from the perspective of the circular economy in the food industry and to promote more environmentally friendly food use.

In conclusion, after the sensory evaluation, we can say fullness and saturation weaken with the increasing concentration of bread and decreasing amount of malt. And there some defects of taste such as salt, kvass/yeast, diacetyl, which are caused by the composition of bread.

As a first sample, lager beer without bread substitute was used. Its lower results in total rating indicate that the evaluators have their preferences in other types of beer.

Sample 5 (40:60), 6 (50:50), and 7 (60:40) with the higher concentration of bread were rated the lowest in the total rating.

Sample 2 (10:90) and 3 (20:80) with the lower concentration of bread were rated the highest in the total rating.
\end{abstract}

Keywords: gastronomic waste, brewery, bakery leftovers

JEL Index: M11, Q01, Q53

\section{Introduction}

Today, beer has become the world's most popular alcoholic beverage. In 2003, worldwide beer consumption was 1,444,087,000 hectolitres (Stack et al. 2016, p. 64) and its amount increased to $1,91 \mathrm{bn} \mathrm{hl}$ in 2019 (Statista 2021). The partial use of bakery leftovers for beer production instead of malt will solve two problems: the waste of bakery leftovers and the loss of resources for growing barley for beer production. Small breweries such as Toast Ale, Crumbs Brewing in Great Britain and Brussels Beer Project in Belgium brew their beer with bread leftovers which replace some of the malted barley.

Food waste is a major topic in the circular economy, which attempts to reduce carbon footprint and improve eco-efficiency (Mak et al. 2019, p. 2). In 2018 was wasted 347 million tons of cereals worldwide (Hegnsholt et al. 2018, p. 2).

https://doi.org/10.11118/978-80-7509-820-7-0129 
Brewing beer as bread baking is an ancient process. The beer was created approximately 10,000 years ago in the Middle East. Some historians say, that beer was created by bread that was wet and laid for some time. Thankfully to yeast in the bread, the fermentation process started. As a result, people obtained alcohol. The components of the beer were determined by the location, where people lived and the availability of the products. For example, in America for brewing beer people used sweet potato, rice in eastern Asia and sorghum in Africa (Denny 2009, p. 14). Also in some Slavic countries exists an ancient drink named Kvass, which is made from bread, water, and sugar.

The research part of the work deals with the production of beer from bread leftovers in the brewery and laboratory tests. It is necessary to focus on the composition of bakery products, their substitute quantity used in the production of beer in relation to enzymes that are already in malt. It is necessary to ask the question - if malt enzymes break down bakery leftovers without the rest of the material. In the case of a negative result, commercial amylase, protease and lipase based enzymes will be used to fully saccharify the material and eliminate surrogate residues. Subsequent work is optimization when the conditions are tuned malt/bakery leftovers in relation to mashing temperature/time and mash composition in relation to additional external enzymes.

A study (Brancoli et al. 2020) showed that the production of beer from bread has large environmental savings in eighteen impact categories, compared to other options for processing bread residues. Savings observed in beer production, e.g. $0.46 \mathrm{~kg}$ eq. $\mathrm{CO} 2$ in the global warming category is the result of replacing malted barley with surplus bread (Brancoli et al. 2020). This is the first study of using bread leftovers and waste that can be used for developing and enhancement circular food waste management.

\section{Methodology}

Bakery leftovers in the form of ordinary bread are obtained from the bakery pilot plant. After the analyses of the composition of each type of bread, e.g. (Table 1), leftovers were used for beer production. We used bread after its expiration date.

Table 1. Chemical composition of the bread used for beer production

\begin{tabular}{|c|c|c|}
\hline & Wheat bread & Rye bread \\
\hline Nutritional information: & In $100 \mathrm{~g}:$ & In $100 \mathrm{~g}:$ \\
\hline Energy & $1062 \mathrm{~kJ} / 253 \mathrm{kcal}$ & $896 \mathrm{~kJ} / 214 \mathrm{kcal}$ \\
\hline Fats: & $2.0 \mathrm{~g}$ & $0,8 \mathrm{~g}$ \\
\hline saturated fatty acids & $0,3 \mathrm{~g}$ & $0,1 \mathrm{~g}$ \\
\hline Carbohydrates: & $51 \mathrm{~g}$ & $45 \mathrm{~g}$ \\
\hline sugar & $3,6 \mathrm{~g}$ & $0,9 \mathrm{~g}$ \\
\hline Proteins & $9,0 \mathrm{~g}$ & $6 \mathrm{~g}$ \\
\hline Salt & $1,3 \mathrm{~g}$ & $1 \mathrm{~g}$ \\
\hline
\end{tabular}


For brewing purposes, wheat-rye and wheat fresh bread were used. We counted how much dry bread we need and then we subtracted $40 \%$ of the water that is in fresh bread.

Example of counting the ratio:

The ratio of bread to malt $20: 80$

The total amount of malt $3124 \mathrm{~g}$

$3124 \times 80 \%=2499,2 \mathrm{~g}$ (malt)

$3124 \times 20 \%=624,8 \mathrm{~g}$ (dry bread)

$40 \%$ of water in fresh bread

$60 \%$ of dry matter in fresh bread

dry bread $/ 60 \%$ of dry matter in fresh bread $=$ fresh bread

$624,8 / 60 \%=1041,3 \mathrm{~g}$ (fresh bread)

We used the ratio of bread to malt from 10:90 to 60:40, e.g. (Table 2). We didn't go below these ratios, because of the results that we get and it's not needed to use more amount of bread in relation to malt in this experiment.

Table 2. The ratio of bread to malt

\begin{tabular}{|c|c|c|c|c|c|}
\hline Sample & $\begin{array}{c}\text { Type of } \\
\text { bread }\end{array}$ & $\begin{array}{c}\text { Bread/Malt } \\
(\%)\end{array}$ & $\begin{array}{c}\text { Bread, dry matter } \\
(\mathrm{g})\end{array}$ & Malt $(\mathrm{g})$ & Water (l) \\
\hline 1 & - & $00: 100$ & - & 3124 & 20 \\
\hline 2 & wheat-rye & $10: 90$ & 312 & 2811 & 20 \\
\hline 3 & wheat-rye & $20: 80$ & 624 & 2499 & 20 \\
\hline 4 & wheat-rye & $30: 70$ & 937 & 2187 & 20 \\
\hline 5 & wheat & $40: 60$ & 1249 & 1874 & 20 \\
\hline 6 & wheat-rye & $50: 50$ & 1562 & 1562 & 20 \\
\hline 7 & wheat & $60: 40$ & 1874 & 1249 & 20 \\
\hline
\end{tabular}

We had 3 times hopping. We used Sladek ( $\alpha$-bitter acids $=4,5-7,0 \%$ w.) for first and second hopping and Saaz (ŽPČ) ( $\alpha$-bitter acids $=2,5-4,0 \%$ w.) for the last hopping, e.g. (Table 3). The international bittering unit (IBU) in beer is 21.6.

Table 3. The ratio of hops

\begin{tabular}{|c|c|c|c|}
\hline Name & $\begin{array}{c}\text { First hopping } \\
00: 00\end{array}$ & $\begin{array}{c}\text { Second hopping } \\
45: 00\end{array}$ & $\begin{array}{c}\text { Third hopping } \\
90: 00\end{array}$ \\
\hline Sladek & $9 \mathrm{~g}$ & $11 \mathrm{~g}$ & \\
\hline Saaz & & & $30 \mathrm{~g}$ \\
\hline
\end{tabular}

The work process of brewing lager beer with the bread substitute:

1. Malt $(\%)+111$ of water $\left(40^{\circ} \mathrm{C}\right)+$ fresh bread $(\%)=$ cook for 10 minutes and stirring.

2. Increase heat to $52^{\circ} \mathrm{C}$ for $10 \mathrm{~min}$ - "protein rest" (Steiner et al. 2011).

3. Increase heat to $62^{\circ} \mathrm{C}$ for $30 \mathrm{~min}$ - " $\beta$-amylase rest" (Hui 2007).

4. Increase the heat to $72^{\circ} \mathrm{C}$ for $30 \mathrm{~min}$ - "saccharification rest" (Hui 2007).

5. Increase the heat to $85^{\circ} \mathrm{C}$ for $5 \mathrm{~min}$. 
6. The liquid is sieved into the draining tub. Pour 5 litres of water $\left(85^{\circ} \mathrm{C}\right)$ used on a sieve and left for 15 minutes.

7. Added 111 of water to the sieve and poured the drained malt into the cooking vessel.

8. In the cooking vessel, cooked the drained malt at $100^{\circ} \mathrm{C}$ for $90 \mathrm{~min}$.

9. Hopping 90 min.

10. 20 minutes it stands.

11. Strained through a small sieve from the cooking vessel.

12. Cool the liquid to $12-16^{\circ} \mathrm{C}$.

13. Add yeast (Saflager W 34/70). Aeration.

14. Refrigerate at $12^{\circ} \mathrm{C}$ for 14 days.

15. After 14 days, beer is transferred to the bottles with added sugar. Refrigerated at $12{ }^{\circ} \mathrm{C}$ for 20 days.

\section{Results}

We examined 7 samples of beer on the device for the automatic analysis of beer Funke Gerber FermentoFlash, e.g. (Table 4).

Table 4. Physical evaluation of beer

\begin{tabular}{|c|c|c|c|c|c|}
\hline Sample & $\begin{array}{c}\text { Alcohol } \\
(\text { weight } \%)\end{array}$ & $\begin{array}{c}\text { Alcohol } \\
(\text { vol. } \%)\end{array}$ & $\begin{array}{c}\text { True extract } \\
(\%)\end{array}$ & $\begin{array}{c}\text { Virtual extract } \\
(\%)\end{array}$ & $\begin{array}{c}\text { Original } \\
\text { wort }(\%)\end{array}$ \\
\hline 1 & 4.36 & 5.25 & 3.41 & 3.24 & 11.53 \\
\hline 2 & 4.21 & 5.11 & 4.41 & 4.91 & 12.37 \\
\hline 3 & 4.60 & 5.59 & 5.14 & 5.86 & 13.85 \\
\hline 4 & 4.46 & 5.39 & 4.25 & 4.53 & 12.62 \\
\hline 5 & 3.88 & 4.72 & 4.61 & 5.38 & 11.98 \\
\hline 6 & 3.33 & 4.05 & 4.05 & 4.77 & 10.38 \\
\hline 7 & 5.07 & 6.13 & 4.92 & 5.29 & 14.45 \\
\hline
\end{tabular}

We conducted the sensory evaluation of beer with 5 evaluators (one woman and four men). We had 7 samples of beer. The evaluation was from 1 to 10 points (10 was the highest), e.g. (Table 5 and 6).

Table 5. Sensory evaluation of beer

\begin{tabular}{|c|c|c|c|c|c|c|}
\hline Sample & $\begin{array}{c}\text { Bread/Malt } \\
(\%)\end{array}$ & Aroma & Taste & Drinkability & $\begin{array}{c}\text { Total } \\
\text { rating }\end{array}$ & EBC \\
\hline 1 & $00: 100$ & 5.8 & 5.8 & 6.8 & 6.2 & $6-8$ \\
\hline 2 & $10: 90$ & 5.2 & 6.6 & 6.8 & 7 & $8-12$ \\
\hline 3 & $20: 80$ & 5.6 & 6.8 & 6.6 & 7 & $8-12$ \\
\hline 4 & $30: 70$ & 5.2 & 6.6 & 6.8 & 6.2 & $8-12$ \\
\hline 5 & $40: 60$ & 5.6 & 5.8 & 5.4 & 5.6 & $4-6$ \\
\hline 6 & $50: 50$ & 5 & 5.6 & 4.4 & 4.4 & $4-6$ \\
\hline 7 & $60: 40$ & 3.2 & 3.2 & 3 & 3.2 & $6-8$ \\
\hline
\end{tabular}


Table 6. Sensory evaluation of beer

\begin{tabular}{|c|c|c|c|c|}
\hline Sample & Foam & Fullness & Saturation & Defects \\
\hline 1 & White, foamy, dry & middle & middle & - \\
\hline 2 & White, foamy, dry & middle & middle & - \\
\hline 3 & White, foamy, dry & strong & strong & - \\
\hline 4 & White, foamy, dry & middle & middle & - \\
\hline 5 & White, foamy, dry & weak & weak & Salt \\
\hline 6 & White, foamy, dry & weak & weak & Kvass, salt \\
\hline 7 & White, foamy, dry & weak & weak & Salt, diacetyl \\
\hline
\end{tabular}

As a first sample, we had lager beer without bread substitute. Its lower results in total rating indicate that the evaluators have their preferences in other types of beer. They evaluated this lager beer from 3 to 9 points in the total rating.

Sample $2(10: 90)$ and $3(20: 80)$ were rated the highest in the total rating.

Sample 5 (40:60), 6 (50:50), and 7 (60:40) were rated the lowest in the total rating.

Also, we analysed few samples of beer and fresh water on some chemical elements and parameters (Table 7).

Table 7. Chemical composition of beers and the water used for brewing

\begin{tabular}{|c|c|c|c|c|c|}
\hline Description & water & $0: 100$ & $20: 80$ & $40: 60$ & $50: 50$ \\
\hline $\mathrm{pH}$ & 7.3 & 4,6 & 4,5 & 4,5 & 4,4 \\
\hline $\mathrm{Cl}-$ & 19,9 & 141 & 821 & 1200 & 985 \\
\hline $\mathrm{SO}_{4}{ }^{2}-$ & $<0,5$ & 72,4 & 73,6 & 55,6 & 52,6 \\
\hline $\mathrm{KNK} 4.5$ & 3,85 & 1,43 & $<0,15$ & 0,57 & $<0,15$ \\
\hline $\mathrm{KNK} 8.3$ & $<0,15$ & $<0,15$ & $<0,15$ & $<0,15$ & $<0,15$ \\
\hline $\mathrm{HCO} 3$ & 235 & 87 & $<3$ & 35 & $<3$ \\
\hline $\mathrm{CO} 3$ & $<3$ & $<3$ & $<3$ & $<3$ & $<3$ \\
\hline $\mathrm{Ca}$ & 98,5 & 95,5 & 98,2 & 152 & 136 \\
\hline $\mathrm{K}$ & 1,44 & 514 & 631 & 326 & 389 \\
\hline $\mathrm{Mg}$ & 3,46 & 114 & 150 & 107 & 113 \\
\hline $\mathrm{Na}$ & 2,73 & 14,9 & 450 & 727 & 586 \\
\hline
\end{tabular}

\section{Discussion}

We started this project work because of the absence of research on this topic, that's why it's problematic to find literature and articles about brewing beer from bread or similar materials.

A study (Brancoli et al. 2020) showed that the production of beer from bread has large environmental savings in sixteen impact categories, compared to other options for processing bread residues: source reduction, donation, animal feed production, ethanol production, anaerobic digestion, and incineration. The functional unit of the study is the prevention of $1 \mathrm{~kg}$ of surplus bread in Sweden. The savings observed from beer production, e.g. $0.46 \mathrm{~kg} \mathrm{CO} 2 \mathrm{eq}$ in the global warming category is the result of replacing malted barley with surplus bread (Brancoli et al. 2020). In this 
research, two recipes were used. The first from the brewery Toast Ale which brews their beer with surplus bread which replaces up to $30 \%$ of barley. The second from the 11th International Conference on Life Cycle Assessment of Food (LCA Food 2018; Almeida et al. 2018). Brancoli et al. used fresh bread as we did, for the energy economy instead of drying bread in the oven. They used just up to $30 \%$ of bread substitute as in recipes they used, in return, we used our original recipe and tried to substitute barley with bread up to $60 \%$.

Small breweries that have open access to their recipes, don't use more than $30 \%$ of bread substitutes in their beers.

Estevão et al. 2021 in the study used malt substitute such as sorghum (45\%), rye malt (45\%), maize (45\%), rice (45\%), and oat malt (45\%).

\section{Conclusion}

As a first sample, we had lager beer without bread substitute. Its lower results in total rating indicate that the evaluators have their preferences in other types of beer. They evaluated this lager beer from 3 to 9 points in the total rating.

Sample 2 (10:90) and 3 (20:80) were rated the highest in the total rating.

Sample 5 (40:60), 6 (50:50), and 7 (60:40) were rated the lowest in the total rating.

To conclude, fullness and saturation weaken with the increasing concentration of bread and decreasing amount of malt. And there some defects of taste such as salt, kvass/yeast, diacetyl, which are caused by the composition of bread.

The weaker fullness in samples 5, 6, and 7 indicates that the lower amount of malt in these samples and lower amount of extracted enzymes from malt, make the beer body weaker. The bread itself, cannot provide that amount of enzymes that make the strong fullness of beer. In proceeding research, we will use commercial amylase, protease and lipase based enzymes to fully saccharification.

Further research must be directed to optimization the conditions between malt and bakery leftovers considering the mashing temperature and time and mash composition in relation to additional external enzymes.

This work was supported by the internal grant project "The perspective of the circular economy of gastronomic waste with regard to the production of beer-based beverages" AF-IGA2021-IP029

\section{References}

1. Almeida J., Thomas J., Murphy K., Griffiths R., Bengtsson J. (2018), Circular Brew: life cycle assessment of waste bread-based beer. In: The 11th International Conference on Life Cycle Assessment of Food (LCA Food 2018) in conjunction with the 6th LCA AgriFood Asia and the 7th International Conference on Green and Sustainable Innovation (ICGSI), Bangkok, Thailand.https://www.lifecycleinitiative.org/event/11th-international-conference-life-cycleassessment-of-food/ access: 30-06-2021 
2. Brancoli P., Bolton K., \& Eriksson M. (2020), Environmental impacts of waste management and valorisation pathways for surplus bread in Sweden. Waste Management, 117, 136-145. https://doi.org/10.1016/j.wasman.2020.07.043

3. Denny M. (2009), Froth! The science of beer. The Johns Hopkins University Press, pp. 183, ISBN-13: 978-0-8018-9132-8

4. Estevão S. T., Batista de Almeida e Silva, J., \& Lourenço F. R. (2021), Development and optimization of beer containing malted and non-malted substitutes using quality by design $(Q b D) \quad$ approach. Journal of Food Engineering, 289, 110182. https://doi.org/10.1016/j.jfoodeng.2020.110182

5. Hegnsholt E., Unnikrishnan S., Pollmann-Larsen M., Askelsdottir B., and Gerard M. (2018), tackling the 1.6-billion-ton food loss and waste crisis, BCG Henderson Institute. https://www.bcg.com/publications/2018/tackling-1.6-billion-ton-food-loss-and-waste-crisis access: 30-06-2021

6. Hui Y.H. (2007), Handbook of Food Products Manufacturing, John Wiley \& Sons, Inc., Hoboken, NJ, USA, https://doi.org/10.1002/0470113553

7. Mak T. M. W., Xiong X., Tsang D. C. W., Yu I. K. M., Sun Poon C. (2019), Sustainable food waste management towards circular bioeconomy: Policy review, limitations and $\begin{array}{lll}\text { opportunities. } & \text { Bioresource } & \text { Technology, }\end{array}$ https://doi.org/10.1016/j.biortech.2019.122497

8. Stack M., Gartland M., \& Keane T. (2016), Path Dependency, Behavioral Lock-in and the International Market for Beer. Brewing, Beer and Pubs, 54-73. https://doi.org/10.1057/9781137466181_4

9. Statista (2021), Jan Conway, Beer Industry - Statistics \& Facts, https://www.statista.com/topics/1654/beer-production-and-distribution/ access: 30-06-2021

10. Steiner E., Gastl M., \& Becker T. (2011), Protein changes during malting and brewing with focus on haze and foam formation: a review. European Food Research and Technology, 232(2), 191-204. https://doi.org/10.1007/s00217-010-1412-6 